\title{
A Method for the Simultaneous Measurement of Insulin Release and B Cell Membrane Potential in Single Mouse Islets of Langerhans
}

\author{
A. M. Scott, I. Atwater and E. Rojas \\ Department of Biophysics, School of Biological Sciences, University of East Anglia, Norwich, Norfolk, UK
}

\begin{abstract}
Summary. A method has been developed for the simultaneous measurement of insulin release and electrical activity in single micro-dissected mouse islets of Langerhans. The effects of D-glucose have been studied in individual islets. Each islet was exposed to 0 , $5.6,11.1,16.7,22.2,27.8$ and $33.3 \mathrm{mmol} / 1$ glucose in a stepwise fashion. The minimum glucose concentration required to elicit spike activity is lower than that required to stimulate insulin release above basal levels and the maximum spike frequency occurs at a lower glucose concentration than does maximum insulin release. Following a reduction in glucose from 27.8 (or 33.3 ) to $5.6 \mathrm{mmol} / 1$, membrane potentials returned to resting values within $2 \mathrm{~min}$ whereas insulin returned to basal values after $20 \mathrm{~min}$. Increasing glucose from 5.6 to $27.8 \mathrm{mmol} / 1$ induced spike activity within $10 \mathrm{~s}$; the insulin response was detected within $40 \mathrm{~s}$. Thus, it is possible to use the single mouse islet for simultaneous measurements of insulin release and electrical activity.
\end{abstract}

Key words: Glucose, B cell, albino mouse, membrane potential, spike frequency, insulin release, islet perifusion, islet of Langerhans.

In recent years several groups have studied the membrane potential fluctuations induced by D-glucose in pancreatic islet cells, identified as B cells by the characteristic pattern of electrical activity in bursts of spikes $[2,12,14,16,17]$. It has been proposed that the action potentials, or spikes, may be correlated with insulin release and either result from or are a stimulus to exocytocis $[2,10,11,12,16,17]$. Although it is possible to measure insulin release from single mouse islets $[4,7,19]$, the simultaneous recording of B cell mem- brane potentials and insulin release from single islets has only recently been reported [3]. In that study, we found that the insulin release in the presence of $11.1 \mathrm{mmol} / 1$ glucose was pulsatile and showed a periodicity close to that of the burst pattern of electrical activity.

It has also been proposed that the cells within an islet of Langerhans function in synchrony, as there is evidence that the $B$ cells are coupled in the presence of glucose $[4,5,6,13,15,18]$. Thus, the electrical recording from one $\mathrm{B}$ cell may be representative of the electrical activity of the majority of the $B$ cells within the islet.

In this study we describe a method for the simultaneous measurement of insulin release with B cell membrane activity from single mouse islets of Langerhans. We have measured the insulin release in response to various levels of glucose up to $33.3 \mathrm{mmol} / \mathrm{l}$ and have made recordings of the membrane potential fluctuations from a B cell in each islet studied. These results have been used to obtain glucose dose-response curves for both insulin release and spike frequency.

\section{Materials and Methods}

\section{Perifusion Chamber}

The chamber used in previous work [2] was modified to be able to record simultaneously the electrical activity from $B$ cells and to collect the perifusate for measurement of the insulin content. The suction outflow was changed for a wedge-shaped groove across one side of the plastic chamber. A short piece of glass capillary was mounted at an angle through this groove; the angle and length of capillary were adjusted so that as each drop of solution formed and fell from the tip and there was no disturbance of the solution within the chamber. This was necessary to avoid dislocation of the microelectrode and termination of the electrical recording. The chamber volume was $40 \mu$ l. The dead space between the stopcock and the 
chamber introduced a time delay of about $3 \mathrm{~s}$. The flow rate through the chamber was controlled at a constant value throughout each experiment by maintaining the perifusion solution at a fixed height above the chamber. The flow rate varied slightly between each experiment, the average being $1.82 \mathrm{ml} / \mathrm{min}$ with a range of 1.74 to $1.85 \mathrm{ml} / \mathrm{min}$. At the end of each experiment the volume of every sample was measured to check that the flow rate had been constant throughout the experiment.

\section{Collection of Samples}

The chamber was orientated at an angle on a heavy metal plate so that the perifusate could drip into a container dissociated from the anti-vibration mounting. In order to avoid any mechanical disturbances, manual collections were made by gently sliding a rack of tubes under this drip.

\section{Insulin Assays}

Following collection, all samples were stored at $-20^{\circ} \mathrm{C}$ until they were assayed for insulin by radioimmunoassay. Mouse insulin was used as standard; ${ }^{125}$ I-labelled bovine insulin was used as the radioactive tracer and guinea-pig anti-porcine insulin serum used as antibody. All dilutions of standards, antibody and radioactive tracer were carried out in $0.05 \mathrm{~mol} / 1$ phosphate buffer containing $0.154 \mathrm{~mol} / 1 \mathrm{NaCl}$ and $0.5 \% \mathrm{BSA}$ (bovine serum albumin), $\mathrm{pH} 7.4$. All samples were assayed in duplicate without dilution; $200 \mu \mathrm{l}$ of sample or standard were incubated with $50 \mu \mathrm{l}$ antibody at $4{ }^{\circ} \mathrm{C}$ for $24 \mathrm{~h}$. Following the addition of $50 \mu \mathrm{l}$ of radioactive tracer the assay was further incubated at $4{ }^{\circ} \mathrm{C}$ for $24 \mathrm{~h}$. Antibody bound and free hormone were separated by the addition of $200 \mu$ l of dextran coated charcoal solution $(2.5 \%$ charcoal, $0.25 \%$ dextran in $0.05 \mathrm{~mol} / \mathrm{l}$ phosphate buffer). Following centrifugation at $4{ }^{\circ} \mathrm{C}$, the supernatant was removed and the radioactivity in the charcoal precipitate counted in a well-type gamma counter. The lower limit of sensitivity of the assay varied slightly between assays, depending on the batch of radioactive tracer used, from 16 to $32 \mathrm{pg}$ insulin $/ \mathrm{ml}$. The intra-assay variation was $8 \%$ and the interassay variation was $14 \%$. Samples collected throughout an experiment were always processed in a single assay to minimize variation.

\section{Calculation of Spike Frequency}

Spike frequency was estimated from the print out of the electrical record made during minutes $8-10$ of the exposure of each islet to a new glucose concentration. Each estimate was made by counting the total number of spikes over a $10 \mathrm{~s}$ interval. Twelve estimates were made for each glucose concentration tested.

\section{Animals}

Albino mice, weighing $25-30 \mathrm{~g}$, with free access to water and standard laboratory chow, were used in this study.

\section{Chemicals}

All chemicals used were of analytical grade unless stated. Mouse insulin was from Novo Research Institute, Denmark. Anti-insulin serum (guinea-pig) was from Wellcome Reagents, Dartford, Kent, UK. ${ }^{125}$ I-bovine insulin was from Radiochemical Centre, Amersham, UK. BSA (Fraction V) was from Armour Pharmaceuticals, Eastbourne, UK. Charcoal (Norit SX 1) was from Hopkin \& Williams, Essex, UK. Dextran T 70 was from Pharmacia, Uppsala, Sweden.

\section{Experimental Procedure}

The electrophysiological methods used in this work have been described previously [2]. The islets were micro-dissected leaving some pancreatic acinar tissue attached to permit holding the islet firmly, by means of pins through this acinar tissue, to the soft plastic covering of the bottom of the chamber. At the end of each experiment the islet was further dissected to permit measurement of three diameters $\left(d_{1}, d_{2}\right.$ and $\left.d_{3}\right)$. These were measured using a dissecting microscope under $\times 100$ magnification and a calibrated eye-piece graticule; islet volume was calculated as $0.52 \times d_{1} \times d_{2} \times d_{3}$. All islets used in this study were dissected from the tail portion of the pancreas. In previous studies of 30 individual islets we observed that only islets with at least two of the three diameters greater than $200 \mu \mathrm{m}$ released sufficient insulin in $20 \mathrm{~s}$ to be detected with our assay. For this reason only large islets were used in this study.

Each islet was perifused with modified Krebs solution $\left(110 \mathrm{mmol} / 1 \quad \mathrm{NaCl}, 5 \mathrm{mmol} / 1 \mathrm{KCl}, 25 \mathrm{mmol} / 1 \quad \mathrm{NaHCO}_{3}\right.$, $2.5 \mathrm{mmol} / 1 \mathrm{CaCl}_{2}, 1.1 \mathrm{mmol} / 1 \mathrm{MgCl}_{2}$, saturated with $95 \% \mathrm{O}_{2} / 5 \%$ $\mathrm{CO}_{2}$, temperature $37.5^{\circ} \mathrm{C}$ ) containing $0.5 \%$ BSA. Glucose at a concentration of $11.1 \mathrm{mmol} / \mathrm{l}$ was present in the perifusion solution until a B cell was impaled (this operation usually took about $20 \mathrm{~min}$ ). Continuous recording of the membrane potential began when the $B$ cell showed stable membrane potentials and the regular burst pattern of electrical activity. Membrane potentials were recorded on magnetic tape (Racal Thermionic, Store 4). The tape recordings were later used for analysis of spike frequency. A second channel was used on the tape recorder as an event marker, simultaneously marking the tape and emitting an audible signal every $20 \mathrm{~s}$ to indicate the time of individual sample collections.

In the present study a B cell was impaled with a micro-electrode in the presence of $11.1 \mathrm{mmol} / 1$ glucose. The solution was then switched to one with zero glucose and the islet was kept in this solution for $10 \mathrm{~min}$. During the last $2 \mathrm{~min}$, six samples ( $20 \mathrm{seach}$ ) of the perifusate were collected. The solution was then switched to one with $5.6 \mathrm{mmol} / \mathrm{l}$ glucose. As before, the islet was perifused with this solution for $10 \mathrm{~min}$ and samples were collected during the last $2 \mathrm{~min}$. This perifusion and collection routine was repeated with $11.1,16.7,22.2,27.8$ and $33.3 \mathrm{mmol} / 1$ glucose solutions in stepwise fashion in six individual islets (BB-16, BB-17, BB-21, BB-22, BB-23 and $\mathrm{BB}-24)$. Following the completion of the glucose dose-response study in each islet, the glucose concentration was lowered to $5.6 \mathrm{mmol} / \mathrm{l}$. Groups of three samples $(20 \mathrm{~s}$ each) were collected at various times for up to $40 \mathrm{~min}$ after the switch from high to low glucose and the insulin content measured. In three additional experiments, individual islets were exposed to $33.3 \mathrm{mmol} / 1$ glucose for $20 \mathrm{~min}$ before switching to $5.6 \mathrm{mmol} / 1$ glucose. At the time of the switch from high to low glucose, $2.5 \mathrm{mmol} / 1 \mathrm{CoCl}_{2}$ was used in the modified Krebs solution in place of the usual $2.5 \mathrm{mmol} / 1 \mathrm{CaCl}_{2}$. Samples of the perifusate were collected continuously for $23 \mathrm{~min}$ starting $3 \mathrm{~min}$ before the switch to low glucose. The samples were collected over $1 \mathrm{~min}$ intervals except during the first 5 min after the addition of $\mathrm{Co}^{2+}$ when they were collected over $20 \mathrm{~s}$ intervals. Membrane potentials were recorded continuously in all experiments.

\section{Results}

\section{Glucose Dose-Response of Insulin Release from Single Perifused Islets}

Figure 1 shows the insulin release and the spike frequency obtained in response to the different concentrations of glucose in six individual islets. In all cases, 


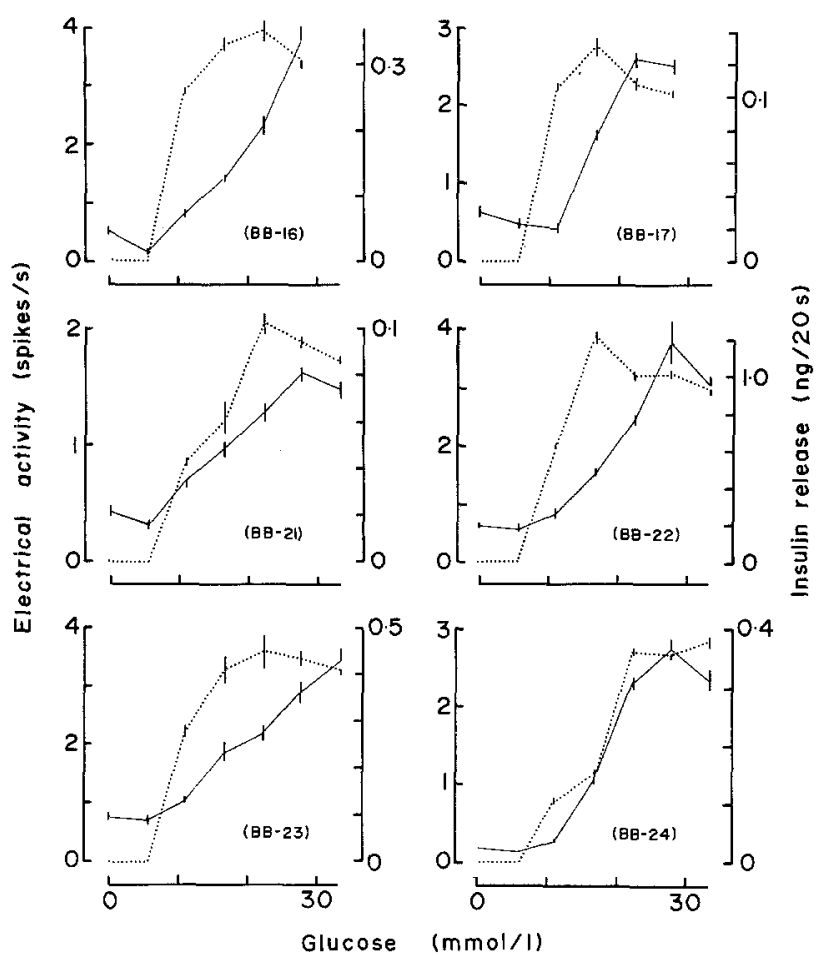

Fig. 1. Simultaneous measurements of spike frequency and insulin release in six individual islets of Langerhans in response to 0, 5.6, $11.1,16.7,22.2,27.8$ and $33.3 \mathrm{mmol} / \mathrm{l}$ glucose. Electrical activity is recorded as spikes $/ \mathrm{s}(|\cdots \cdots|)$. Each point represents the mean of 12 samples of spike activity recorded during minutes $8-10$ of the perifusion at each glucose concentration. Insulin release is recorded as $n g / 20 \mathrm{~s}(|-|)$. Each point represents the mean of six samples collected during minutes $8-10$ of the perifusion at each glucose concentration. Vertical bars represent mean \pm SEM. Experiment number for each islet studied, BB-16, BB-17, BB-21, BB-22, BB-23, BB-24 is given on each individual graph. Vertical scales are different for each islet

the insulin release was significantly increased as the concentration of glucose was increased beyond $11.1 \mathrm{mmol} / 1$. In three experiments the insulin output from the islet reached a maximum at $27.8 \mathrm{mmol} / 1 \mathrm{glu}-$ cose (BB-21, BB-22 and BB-24). The insulin output from one of the islets (BB-17) reached a maximum at $22.2 \mathrm{mmol} / \mathrm{lglucose}$. In the other two, the insulin output had not saturated at $27.8 \mathrm{mmol} / 1$ glucose (BB-16) or $33.3 \mathrm{mmol} / 1$ glucose (BB-23).

\section{Membrane Potential as a Function of Glucose}

After identification of an active B cell by the typical burst pattern of electrical activity in $11.1 \mathrm{mmol} / 1 \mathrm{glu}-$ cose, the islet was exposed to glucose-free solution for $10 \mathrm{~min}$. In all cases, the membrane hyperpolarized and electrical activity was suppressed. None of the $B$ cells examined was electrically active during the $10 \mathrm{~min}$ exposure to $5.6 \mathrm{mmol} / \mathrm{l}$ glucose. Upon switch-
Table 1. Glucose-induced insulin release in six individual islets of Langerhans

\begin{tabular}{llrrr}
\hline $\begin{array}{llll}\text { Experiment } \\
\text { No. }\end{array}$ & $\begin{array}{l}\text { Islet volume } \\
(\mathrm{cm})\end{array}$ & \multicolumn{2}{l}{ Insulin release } & \multirow{2}{*}{\begin{tabular}{l} 
Ratio \\
\cline { 3 - 4 }
\end{tabular}} \\
& & $\begin{array}{l}\text { Glucose } \\
5.6 \mathrm{mmol} / 1 \\
(\mathrm{ng} / 20 \mathrm{~s})\end{array}$ & $\begin{array}{l}\text { Glucose } \\
27.8 \mathrm{mmol} / 1 \\
(\mathrm{ng} / 20 \mathrm{~s})\end{array}$ & \\
\hline BB-16 & $1.6 \times 10^{-5}$ & 0.015 & 0.339 & 22.6 \\
& & \pm 0.002 & \pm 0.026 & \\
BB-17 & $0.6 \times 10^{-5}$ & 0.024 & 0.119 & 5.0 \\
& & \pm 0.003 & \pm 0.004 & \\
BB-21 & $0.1 \times 10^{-5}$ & 0.016 & 0.081 & 5.1 \\
& & \pm 0.002 & \pm 0.003 & \\
BB-22 & $6.9 \times 10^{-5}$ & 0.186 & 1.196 & 6.4 \\
& & \pm 0.019 & \pm 0.123 & \\
BB-23 & $1.6 \times 10^{-5}$ & 0.089 & 0.366 & 4.1 \\
& & \pm 0.008 & \pm 0.021 & \\
BB-24 & $3.0 \times 10^{-5}$ & $<0.019$ & 0.368 & 19.4 \\
& & & \pm 0.018 & \\
\hline Mean & $2.3 \times 10^{-5}$ & 0.058 & 0.411 & 10.4 \\
& & \pm 0.028 & \pm 0.166 & \pm 3.4 \\
\hline
\end{tabular}

All values for insulin release are expressed as mean $\pm \operatorname{SEM}(n=6)$

ing to a solution containing $11.1 \mathrm{mmol} / 1$ glucose, the electrical activity followed a biphasic pattern with the spike frequency increasing at first and decreasing after a few min. After switching to a solution containing $16.7 \mathrm{mmol} / 1$ glucose, the electrical activity increased, again in a biphasic manner. The cells studied in experiments BB-16, BB-21 and BB-23 showed spike activity in bursts in the presence of $16.7 \mathrm{mmol} / 1$ glucose, while the others showed continuous spike activity. Upon increasing glucose concentration to $22.2,27.8$ and $33.3 \mathrm{mmol} / 1$, spike activity remained continuous in all cells studied. In four of the cells studied the spike frequency reached a maximum at $16.7 \mathrm{mmol} / \mathrm{l}$ glucose (BB-16, BB-17, BB-22 and BB-23), while in two of the cells the spike frequency reached a maximum at $22.2 \mathrm{mmol} / 1$ glucose (BB-21) and (BB-24). The spikes in 27.8 and $33.3 \mathrm{mmol} / 1$ glucose were longer in duration and consisted of multiple peaks, which were not included in the spike frequency estimation.

\section{Variability of Insulin Release from Islet to Islet}

Insulin release in response to glucose varied from islet to islet. Table 1 compares the approximate size of the islet used in each experiment with the concentration of insulin in the perifusate in the presence of 5.6 or $27.8 \mathrm{mmol} / 1$ glucose. There appears to be a correlation between islet size and amount of insulin released. Thus, in response to $27.8 \mathrm{mmol} / 1$ glucose the largest 

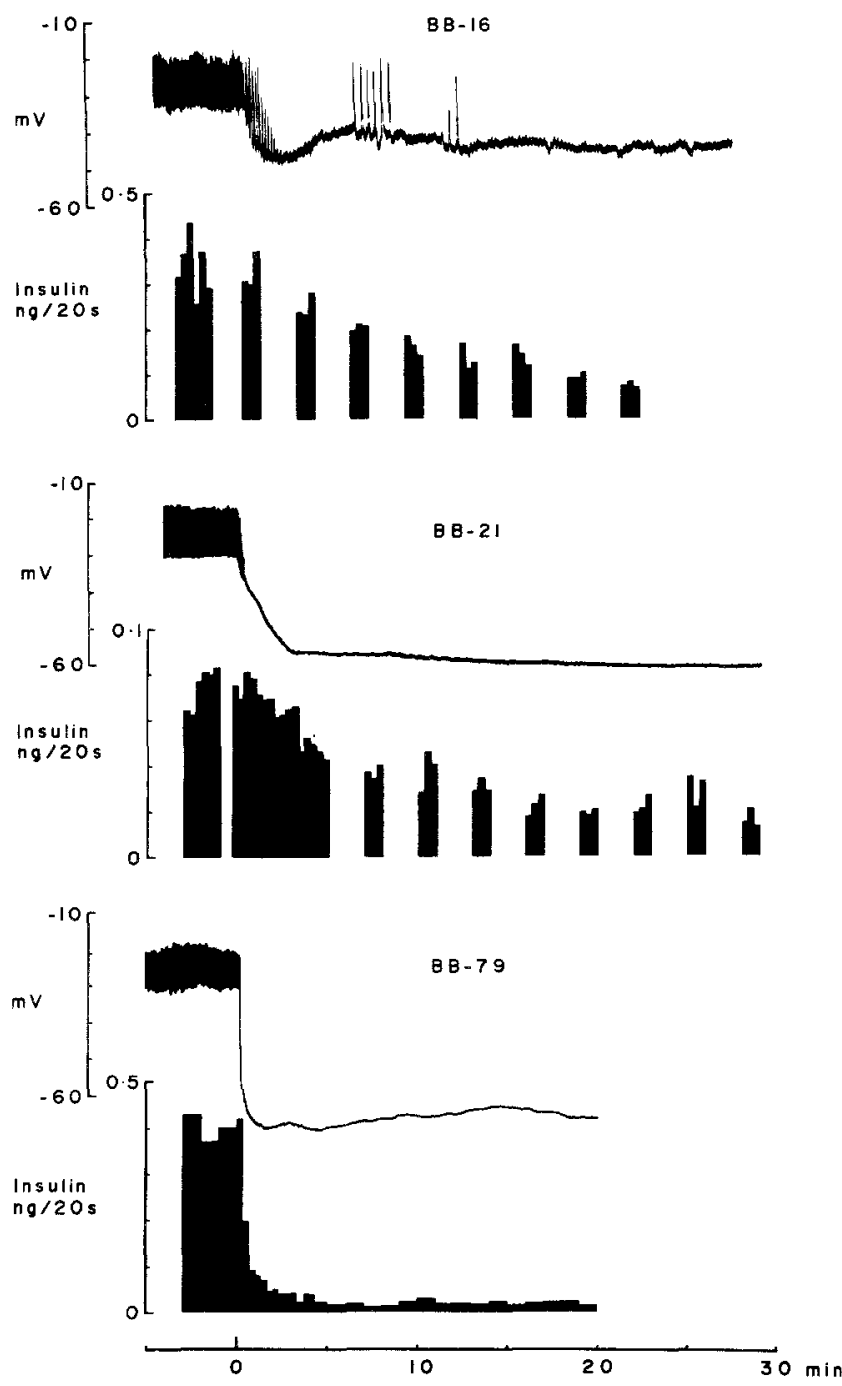

Fig. 2. Comparison of B cell membrane potential with insulin release after a sudden decrease in glucose concentration: effect of Cobalt. The upper part of each experiment depicted represents the electrical activity recorded from a B cell in a single, isolated islet of Langerhans during a $20-30$ min period. The lower part of each experiment represents the amount of insulin in the perifusate during the time at which the electrical recording was made. At time 0 , glucose concentration in the perifusate solution was lowered from $27.8 \mathrm{mmol} / \mathrm{l}$ (BB-16) or $33.3 \mathrm{mmol} / \mathrm{l}$ (BB-21, BB-79) to $5.6 \mathrm{mmol} / 1$. During experiment BB-79, $2.5 \mathrm{mmol} / 1 \mathrm{Co}^{2+}$ was substituted for $2.5 \mathrm{mmol} / 1 \mathrm{Ca}^{2+}$ in the perifusion solution at time 0

islet (BB-22) released about 14 times more insulin than the smallest islet (BB-21). Table 1 also gives the degree of stimulation from each islet, using the ratio of the insulin release in the presence of $27.8 \mathrm{mmol} / 1$ to that in $5.6 \mathrm{mmol} / \mathrm{l}$. On average the islets released 10.4 times more insulin in the presence of $27.8 \mathrm{mmol} / 1 \mathrm{glu}$ cose than in the presence of $5.6 \mathrm{mmol} / 1$ glucose.

Spike frequency does not appear to correlate with islet size. In $11.1 \mathrm{mmol} / 1$ glucose it ranged from 0.8 to
2.9 spikes $/ \mathrm{s}$. In $22.2 \mathrm{mmol} / 1$ glucose the spike frequency ranged from 2 to 4 spikes/s.

\section{The Effect of Removal of the Glucose Stimulus}

Following the completion of the glucose dose-response curves in each islet, the effect of lowering the glucose level to $5.6 \mathrm{mmol} / \mathrm{l}$ on insulin release and membrane potential was examined. In all cases the insulin fell exponentially towards the original level of insulin release in response to $5.6 \mathrm{mmol} / 1$ glucose at the beginning of the dose-response study. The average time constant, $\tau$, was $12.6 \pm 1.0 \mathrm{~min}$ (SEM). In four of the islets there was an 'off response', that is, a transient increase in the insulin output from the islet after the glucose concentration in the perifusate had been lowered to $5.6 \mathrm{mmol} / \mathrm{l}$ (BB-17, BB-22, BB-23 and BB-24).

Following the switch to low glucose, the membrane potential recorded from cells within the six islets had reached a value of about $-50 \mathrm{mV}$ within $2 \mathrm{~min}$. None of the cells studied showed an electrical "off response" or transient increase in activity. In two of the islets (BB-16 and BB-23), the cells responded 7-8 min after the switch with a short period of burst activity following the hyperpolarization. There was no activity seen in the other four cells after the initial hyperpolarization induced by switching to $5.6 \mathrm{mmol} / 1$ glucose.

In three experiments, the time course of the return of insulin to basal levels after exposure to $33.3 \mathrm{mmol} / 1$ glucose for $20 \mathrm{~min}$ was studied substituting cobalt for calcium at the time of switching from high to low glucose. In these experiments, spike activity was suppressed within a few seconds and the membrane was repolarized to values of $-50 \mathrm{mV}$ in less than $1 \mathrm{~min}$. The time constant for the return of insulin in the perifusate to basal levels was reduced to less than $1 \mathrm{~min}$ in all three experiments. Figure 2 illustrates three representative experiments; BB-16 and BB-21, showing the effects of a sudden drop in the glucose concentration to $5.6 \mathrm{mmol} / 1$ after a dose-response study, and BB-79, showing the effects of replacement of $\mathrm{Ca}^{2+}$ by $\mathrm{Co}^{2+}$ at the time of reduction of glucose to $5.6 \mathrm{mmol} / 1$. Tracings of the membrane potential from each experiment are shown together with the insulin release as measured from the perifusate over a 20-30 min period.

\section{Time Course of the Onset of Insulin Release}

The delay between the onset of electrical activity and the appearance of insulin in the samples of perifusion solution was measured in response to a sudden glucose stimulus (changing from $5.6 \mathrm{mmol} / 1$ to a higher 
glucose concentration) in several islets. Figure 3 illustrates the data from one such experiment (BB-16). The upper part shows the tracings of the membrane potential recording and the lower part shows the time course of the appearance of insulin in the samples. The recording of the membrane potential was continuous; collection of samples for insulin assay took place between minutes $2-13$ and 17.6-18.3. Columns indicate the amount of insulin in the sample which were collected over $20 \mathrm{~s}$ periods. In the presence of $5.6 \mathrm{mmol} / 1$ glucose the membrane potential was $-45 \mathrm{mV}$. A sudden increase in glucose to $27.8 \mathrm{mmol} / 1$ induced a depolarization followed by a rapid onset of spike activity within $10 \mathrm{~s}$ of switching the solutions. Initially the spikes were about $20 \mathrm{mV}$ in amplitude and occurred with a frequency of 13 spikes/s. At the end of the 2-min period of glucose stimulation the spike frequency decreased to 3.5 spikes/s. The membrane gradually depolarized about $10 \mathrm{mV}$ during the stimulation. Upon returning to the solution containing $5.6 \mathrm{mmol} / 1$ glucose, the spikes were suppressed after $40 \mathrm{~s}$ and the membrane repolarized to a maximum value of about $-50 \mathrm{mV}$ within $80 \mathrm{~s}$.

The basal level of insulin released from this islet in the presence of $5.6 \mathrm{mmol} / 1 \mathrm{glucose}$ was $0.048 \mathrm{ng} /$ $20 \mathrm{~s}$. Upon introduction of $27.8 \mathrm{mmol} / 1$ glucose, the insulin content in the perifusate started to rise within $40 \mathrm{~s}$ and steadily rose to a maximum of $0.368 \mathrm{ng} / 20 \mathrm{~s}$ during the 2 min exposure to high glucose. This value is comparable to the level of insulin measured from the same islet in response to $27.8 \mathrm{mmol} / 1$ glucose during the dose response study, $0.339 \mathrm{ng} / 20 \mathrm{~s}$. After returning to the solution containing $5.6 \mathrm{mmol} / 1 \mathrm{glu}-$ cose, insulin levels in the perifusate fell slowly towards the basal level. At min 19 (13 min after removal of the stimulus), insulin in the perifusate had fallen to $0.103 \mathrm{ng} / 20 \mathrm{~s}$, about double the previous basal level.

\section{Discussion}

The experiments described here represent the first major attempt to correlate $B$ cell activity to the insulin release from the same islet and show the feasibility of measuring insulin from single mouse islets with a relatively fast time resolution.

The glucose-stimulated insulin release was relatively high, probably due to the fact that the islets used were larger than average $[20,21]$ and were selected from the tail portion of the pancreas which contains a higher percentage of B cells [11]. The glucose dose-response curve for insulin release in these experiments was sigmoidal in shape with a maximum between 22.2 and $33.3 \mathrm{mmol} / 1$ glucose, similar to the results ob-

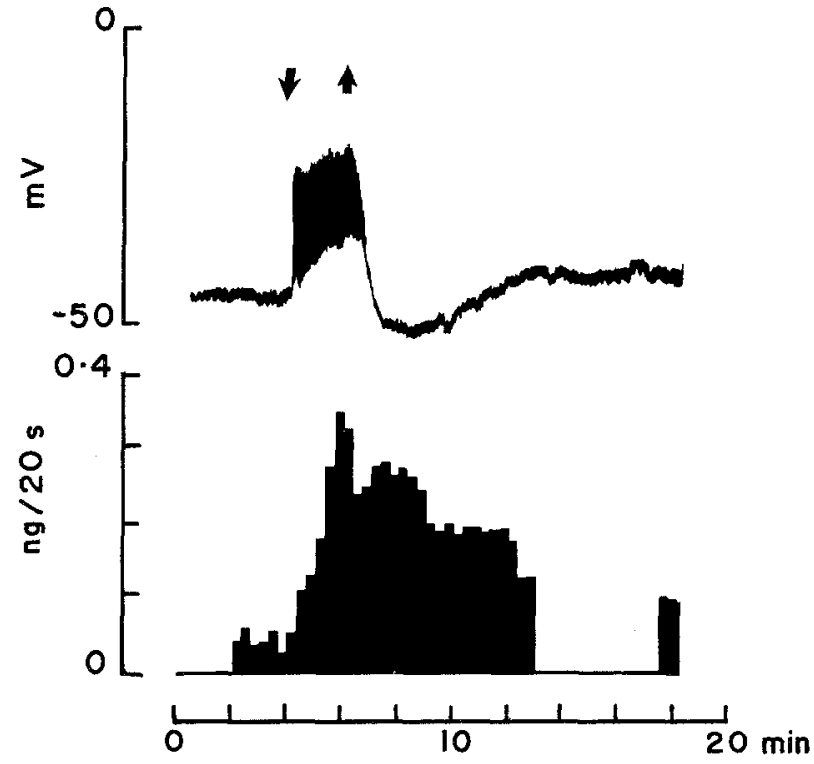

Fig. 3. Comparison of the onset of insulin release with cell membrane depolarization and spike activity in response to glucose. Upper part represents electrical activity recorded from a B cell in a single isolated islet of Langerhans and lower part represents amount of insulin in the perifusate during the time at which the electrical recording was made. Perifusion solution contained $5.6 \mathrm{mmol} / 1$ for $30 \mathrm{~min}$ before time 0 and up to $\mathrm{min} 4,27.8 \mathrm{mmol} / 1$ giucose from $\mathrm{min} 4-6$ (as indicated by the arrows) and $5.6 \mathrm{mmol} / \mathrm{l}$ glucose thereafter. Experiment BB-16

tained by others in spite of the difference in protocol [1].

The spike frequency recorded from a cell within each islet studied showed a sigmoidal response as a function of glucose, similar to that reported earlier [14]. However in the present studies the steady-state spike frequency was decreased at glucose concentrations above $27.8 \mathrm{mmol} / \mathrm{l}$. A transient increase was often observed immediately after each increase in glucose concentration with steady-state values being reached after 4-5 $\mathrm{min}$.

Under steady-state conditions, the glucose doseresponse curve for spike frequency was different from that for insulin release in all six islets studied. The minimum glucose concentration required to elicit spike activity was lower than that required to stimulate insulin release above basal levels (between 5.6 and $11.1 \mathrm{mmol} / \mathrm{l}$ compared with between 11.1 and $16.7 \mathrm{mmol} / \mathrm{l}$ ) and the maximum spike frequency occurred at a lower glucose concentration than did the maximum insulin release (between 16.7 and $27.8 \mathrm{mmol} / 1$ compared with between 22.2 and $33.3 \mathrm{mmol} / \mathrm{l}$ ). Since the electrical response was recorded from only one cell, this discrepancy could be due to a heterogeneous response between different $B$ cells within an islet. This explanation is unlikely if one considers that the $\mathrm{B}$ cell impaled represents a random 
selection of the islet cell population. However, it is possible that the process of impalement with a glass microelectrode may damage the individual cell, causing some depolarization and leading to a shift in the glucose dose-response curve for that cell. Alternatively, the discrepancy between maximal spike frequency and maximal insulin release may result from an increased duration of the spikes in the presence of high glucose.

A discrepancy was also apparent between spike activity and insulin release during the return to basal levels after switching from high glucose to $5.6 \mathrm{mmol} / 1$ glucose. While the spike activity was suppressed and the membrane was repolarized after about $2 \mathrm{~min}$, insulin release did not return to basal levels for as long as $30 \mathrm{~min}$. Although neighbouring $B$ cells have been shown to remain electrically coupled in the presence of $5.6 \mathrm{mmol} / 1$ glucose [6], it is possible that the rapid cessation of electrical activity recorded in all six cells were unrepresentative of the active B cells. A slow wash-out of the insulin from the chamber and tissue can be disregarded since the substitution of cobalt [8] for calcium upon switching to the lower glucose concentration reduced the time-constant for insulin wash-out to less than $1 \mathrm{~min}$. It remains an intriguing possibility that the slow time course of the return of insulin to basal levels after a large glucose stimulus may reflect a continued release of granules after cessation of spike activity and repolarization of the membrane. Clearly further studies are needed to clarify the process.

There is good agreement between the time course for the onset of electrical activity and insulin release in the single islet perifusion system described here. The $20-40$ s delay between the onset of spike activity and onset of insulin release can be reasonably attributed to the delay of insulin dissolution in the extracellular space and diffusion out of the islet.

In conclusion, our results generally support the hypothesis that insulin release is associated with the appearance of action potentials in the $\mathrm{B}$ cell. The single islet has been shown to be a feasible preparation for the simultaneous study of insulin release and $B$ cell membrane potential.

Acknowledgements. We wish to thank Dr. S. Ashcroft for his suggestions during the development of the insulin assay and Dr. C. Dawson for her help during the development of the techniques. We thank Mrs. S. Garrod for the careful typing of the manuscript. This research was supported in part by the British Diabetic Association and the Wellcome Trust.

\section{References}

1. Ashcroft SJH, Bassett JM, Randle PJ (1972) Insulin secretion mechanisms and glucose metabolism in isolated islets. Diabetes $21: 538-545$
2. Atwater I, Beigleman PM (1976) Dynamic characteristics of electrical activity in pancreatic B-cells. I. Effects of calcium and magnesium removal. J Physiol (Paris) 72: 769--786

3. Atwater I, Rojas E, Scott A (1979) Simultaneous measurements of insulin release and electrical activity from single microdissected mouse islets of Langerhans. J Physiol (London) 291: 57P

4. Beigelman PM, Thomas LJ, Slavin B, Shu MJ, Bessman SP (1973) Insulin from individual isolated islets of Langerhans. I: Response to glucose. Biochem Med 8: 392-402

5. Eddlestone GT, Rojas E (1980) Evidence of electrical coupling between mouse pancreatic B-cells. J Physiol (London) 303:76P

6. Eddlestone GT, Rojas E (1980) Electrical coupling between B-cells in the mouse islet of Langerhans. Diabetologia 19:272

7. Hellman B (1970) Methodological approaches to studies on the pancreatic islets. Diabetologia 6:110-120

8. Henquin J-C, Lambert AE (1975) Cobalt inhibition of insulin secretion and calcium uptake by isolated rat islets. Am J Physiol 288: $1669-1677$

9. Malaisse-Lagae F, Stefan Y, Cox J, Perrelet A, Orci L (1979) Identification of a lobe in the adult human pancreas rich in pancreatic polypeptide. Diabetologia 17:361-365

10. Matthews EK (1975) Calcium and stimulus-secretion coupling in pancreatic islet cells. In: Carfoli $E$ (ed) Calcium transport in contraction and secretion. North Holland Publishing Company, Amsterdam, pp 203-210

11. Matthews EK, Dean PM (1970) Electrical activity in islet cells. In: Falkner S, Hellman B, Taljedal I-B (eds) The structure and metabolism of the pancreatic islets. Wenner-Gren Symposium No. 16. Pergamon Press, Oxford New York, pp 305-313

12. Matthews EK, Sakamoto Y (1975) Electrical characteristics of pancreatic islet cells. J Physiol (London) 246:421-437

13. Meda P, Perrelet A, Orci L (1979) Increase of gap junctions between pancreatic B-cells during stimulation of insulin secretion. J Cell Biol 82:441-448

14. Meissner HP (1976) Electrical characteristics of the B-cells in pancreatic islets. J Physiol (Paris) 72:757-767

15. Meissner HP(1976) Electrophysiological evidence for coupling between B-cells of pancreatic islets. Nature 262: 502-504

16. Meissner PH, Preissler M (1979) Glucose-induced changes of the membrane potential of pancreatic B-cells: Their significance for the regulation of insulin release. In: Camerini-Davalos R, Hanover B (eds) Treatment of early diabetes. Plenum Press, New York, pp 97-107

17. Meissner HP, Schmelz H (1974) Membrane potential of B-cells in pancreatic islets. Pfluegers Arch 351: 195-206

18. Orci L, Unger RH, Renold AE (1973) Structural coupling between pancreatic islet cells. Experientia 29: 1015-1018

19. Panten U, Ishida H, Schauder P, Frerichs H, Hasselblatt A (1977) A versatile microperfusion system. Analytical Biochem $82: 317-326$

20. Reaven E, Gold G, Walker W (1980) Effect of variations in islet size and shape on glucose stimulated insulin secretion. Diabetes 29: 106A

21. Steinke J, Patel TN, Ammon HPT (1972) Relationship between glucose and tolbutamide-induced insulin release and insulin content in single pancreatic rat islets. Metabolism $21: 465-470$

Received: 10 December 1980

and in revised form: 18 May 1981

Dr. Angela Scott

Biophysics Department

School of Biological Sciences

University of East Anglia

Norwich NR4 7TJ, UK 